Holocene with a decreasing summer monsoon. In arid northwest China, high Holocene lake shorelines normally date to before $7 \mathrm{cal} k \mathrm{ka}$. This accords with a period of high lakelevels reported from Mongolia and central Asia (e.g. Lehmkuhl and Lang, 2001; Grunert et al., 2000). The strongest drought interval, shown clearly in Figure 2, was from 7.2 cal ka to about 5.0 cal ka. Generally, lakes in the southern Mongolian Plateau were found to have undergone low lake levels or even dry lake bed sequences during the mid-Holocene (Chen C-T. A. et al., 2003). In addition, a Holocene soil (paleosol $\mathrm{S}_{0}$ ) was interrupted by a dust deposit layer around $6 \mathrm{ka}$ ago in the Chinese Loess Plateau (Huang et al., 2000). All of this supports the notion that a mid-Holocene drought existed in regions of the Chinese Loess Plateau and southern Mongolian Plateau.

This mid-Holocene drought was only the most intense and longest of a number of droughts that occurred throughout the Holocene
(Fig. 1). Seven droughts, lasting a few centuries to a few millennia, are recorded in pollen proxies in the SJC section during the Holocene. The droughts are shown by changes in pollen concentrations representing total drainage vegetation coverage, high-elevation vegetation pollen concentrations representing mainly forest vegetation coverage, and Picea-Pinus pollen content representing moisture (Fig. 3). The seven droughts were at $0-0.5 \mathrm{cal}$ ka, 1.2-1.9 cal ka, 2.7-3.2 cal ka, 5.07.2 cal ka, 8.3-8.8 cal ka, 9.2-9.7 cal ka and 10.4-11.2 cal ka, based on our chronology. A possible eighth drought occurred at $7.7 \mathrm{cal} \mathrm{ka}$. The droughts correlate well with changes in hematite-stained grains of core VM29-191 in the Northern Atlantic Ocean, a proxy of ice-rafting events and, thus, temperature (Bond et al., 2001), and with potassium ion content in the GISP2 ice core (Mayewski et al., 1997), a proxy of change in the Siberian-Mongolian High and atmospheric dust (Mayewski et al.,
2004). This supports a hemispherescale correlation of central and millennial climatic events during the present warm interglacial.

\section{REFERENCES}

An, C.-B., Feng, Z., Barton, L., 2005. Dry or Humid? Mid Holocene humidity changes in arid and semiarid China. Quaternary Science Reviews, in press Bond, G., Kormer, B., Beer, J., Muscheler, R., Evans, M. N., Showers, W., Hoffmann, S., Lotti-Bond, R., Hajdas, I. and Bonani G., 2001. Persistent solar influence on North Atlantic climate during the Holocene. Science 294, 2130-2136.

Chen, C-T. A., Lan, H-C., Lou, J-Y., Chen, Y-C., 2003 The dry Holocene Megathermal in Inner Mongolia. Palaeogeography Palaeoclimatology Palaeoecology, 193, 181-200.

Chen, F.H., Wu, W., Holmes, J.A., Madsen, D.B., Zhu, Y., Jin, M. and Oviatt, C.G., 2003. A mid-Holocene drought interval as evidenced by lake desiccation in the Alashan Plateau, inner Mongolia China. Chinese Science Bulletin, 48(14), 1401-1410.

Grunert. J., Lehmkuhl, F., Walther, M., 2000 Paleoclimatic evolution of the Uvs Nuur basin and adjacent areas (Western Mongolia). Quaternary International, 65/66: 171-192

For full references please consult:

www.pages-igbp.org/products/newsletters/ref2005_2.htm

\title{
Grain-size Record of Stepwise Expansion of the Mu Us Desert for the Past $3.5 \mathrm{Ma}$
}

\section{Zhongli Ding and SHILING Yang}

Institute of Geology and Geophysics, CAS, Beijing 100029, China; zlding@mail.igcas.ac.cn; yangsl@mail.igcas.ac.cn

The Mu Us Desert lies immediately north of the Loess Plateau in northern China (Fig. 1). A reconstruction of the desert environment has demonstrated that the southern margin of the desert migrated several hundred km north of its Last Glacial Maximum (LGM, 20 ka BP) limit in response to increased monsoon rainfall during the Holocene Optimum ( 8-4 ka BP) (Sun et al., 1998). However, little is known about the long-term evolution of this monsoon-sensitive environment because of the sparseness of directly extractable geological evidence of suitable type and quality to be found within it. In this report, we'll first show, on the basis of the spatial grain-size changes of three north-south loess transects across the Chinese Loess Plateau, that sand-sized particle content within loess can be used to assess the shift of the southern desert margin. We then present a

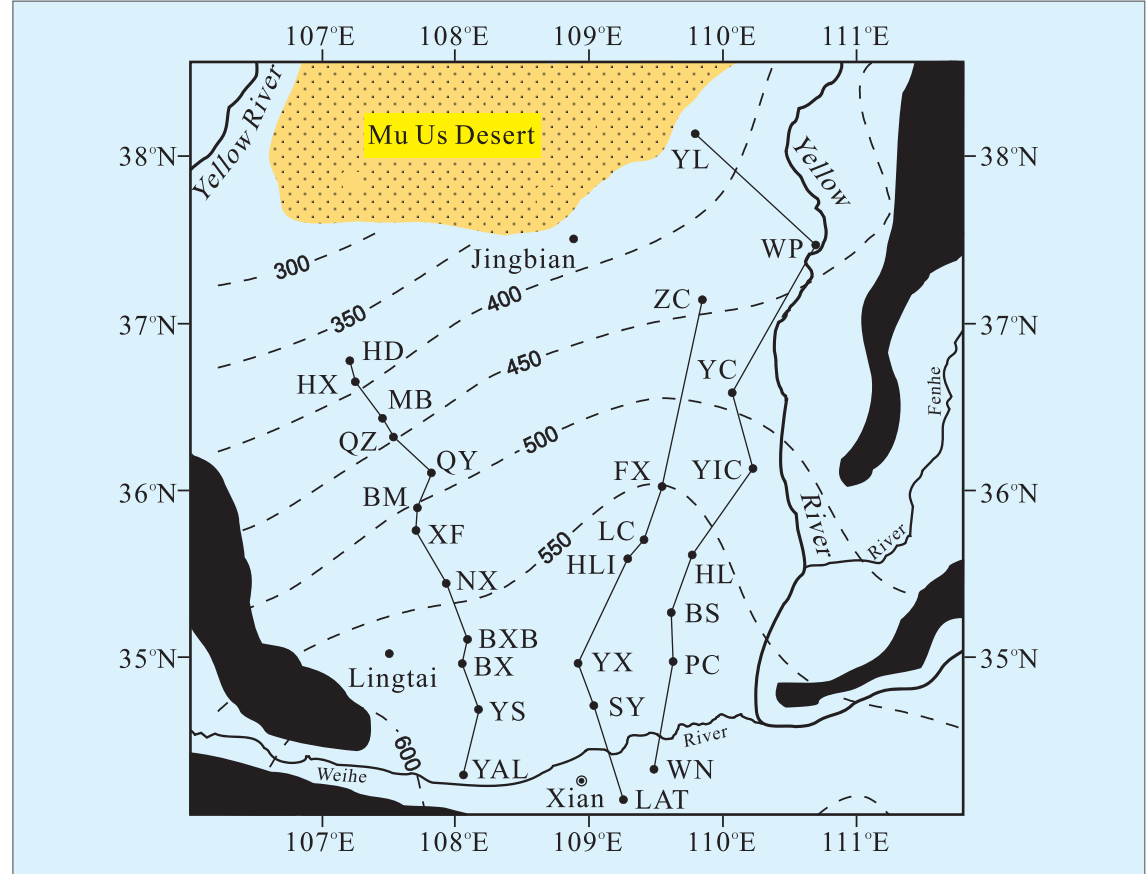

Fig. 1: The sampling localities and annual precipitation isopleths $(\mathrm{mm})$ in the Loess Plateau. grain-size record of loess-red clay deposits from the desert-loess transitional zone to provide insight into the evolutional history of the Mu Us Desert during the Plio-Pleistocene period. The three loess transects are 

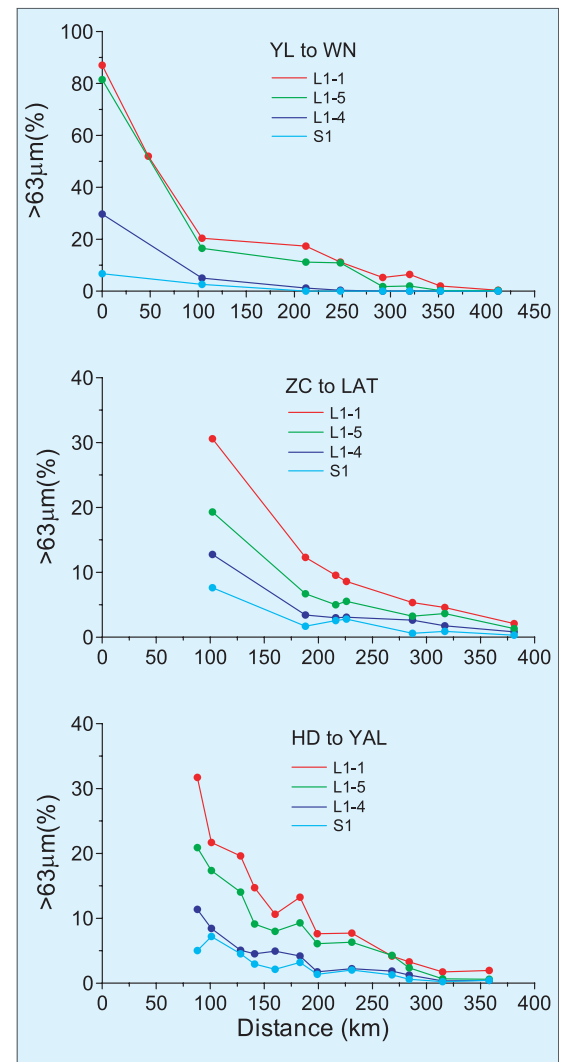

Fig. 2: Changes in the content of sand-sized particles southward from the southern border of the Mu Us Desert (Fig. 1) for L1-1, L1-4, L 1-5 and S1.

from Hongde (HD) to Yangling (YAL), Zichang (ZC) to Lantian (LAT), and Yulin (YL) to Weinan (WN) (Fig. 1), and respectively consist of 12,8 , and 7 sections covering the last glacial cycle. Closely-spaced samples were taken and analyzed for all the sections, and the grain-size curves are well-correlated among the sections (not shown). Theoretical and experimental studies by Pye (1987) and Tsoar and Pye (1987) concluded that during low-level atmospheric dust storms, sand-sized particles are usually transported by saltation or modified saltation near desert surfaces, and that any sand particles transported in suspension quickly settle back onto the ground surface. We thus plotted changes in sand-sized particle content within loess with increasing distance southward of the present southern desert margin for four representative stratigraphic units: L1-1, L1-4, L1-5 and S1 (Fig. 2). Loess units L1-1, L1-4, L1-5 and S1 accumulated respectively in marine isotope stages 2, 3, 4 and 5 . As shown in Fig. 2, all horizons exhibit a consistent southward decrease in the sand particle content, the rate of decrease for L1-1 and L1-5 being more rapid than that for $\mathrm{L} 1-4$ and $\mathrm{S} 1$. Both the L1-1 and L1-5 records show an abrupt decrease near the desert margin and a gradual decrease beyond. According to the reconstruction of Sun et al. (1998), the southern border of the Mu Us Desert during the cold-dry LGM (L1-1) was broadly similar to that of today, whereas it retreated several hundred $\mathrm{km}$ to the north during the warm-humid Holocene Optimum. This implies that this desert margin experienced wide-ranging advance-retreat cycles in response to climatic oscillations at orbital time-scales. It is clear that significant increase in sand percentages in L1-1 and L1-5 relative to S1 and L1-4 were controlled at the first order by the desert advance during their accumulation. Using the sand content-distance relation of L1-1 (Fig. 2), it is therefore inferred that sand particle contents of $\sim 30 \%$ and $~ 15 \%$ within the loess indicate a distance from the desert margin of $\sim 100 \mathrm{~km}$ and $\sim 200 \mathrm{~km}$, respectively.
The Jingbian section $\left(37^{\circ} 40^{\prime} 54^{\prime \prime} \mathrm{N}\right.$, $\left.108^{\circ} 31^{\prime} 15^{\prime \prime} \mathrm{E}\right)$, at $1,370 \mathrm{~m}$ a.s.l., is located only $\sim 12 \mathrm{~km}$ south of the present margin of the Mu Us Desert. The section is composed of a $252-\mathrm{m}$ thick Pleistocene loess-soil sequence resting on a $\sim 30 \mathrm{~m}$ Pliocene red clay deposit. A previous magnetic polarity study showed that this sequence has a basal age of $3.5 \mathrm{Ma}$ (Ding et al., 1999). Field observations have demonstrated that the Pleistocene loesssoil stratigraphy correlates well with the classic loess sections. To the best of our knowledge, the Jingbian section is the only desert margin eolian sequence known to cover the whole Pleistocene and the late Pliocene. Its proximity to the dust source region makes it ideal for the study of longterm desert changes.

The Jingbian magnetic susceptibility and grain-size records, plotted on the Chiloparts timescale (Ding et al., 2002), are shown in Fig. 2, together with a composite marine oxygen isotope record (Shackleton and Pisias, 1985; Shackleton et al., 1990, 1995). The $>63 \mu \mathrm{m} \%$ and $>125 \mu \mathrm{m} \%$

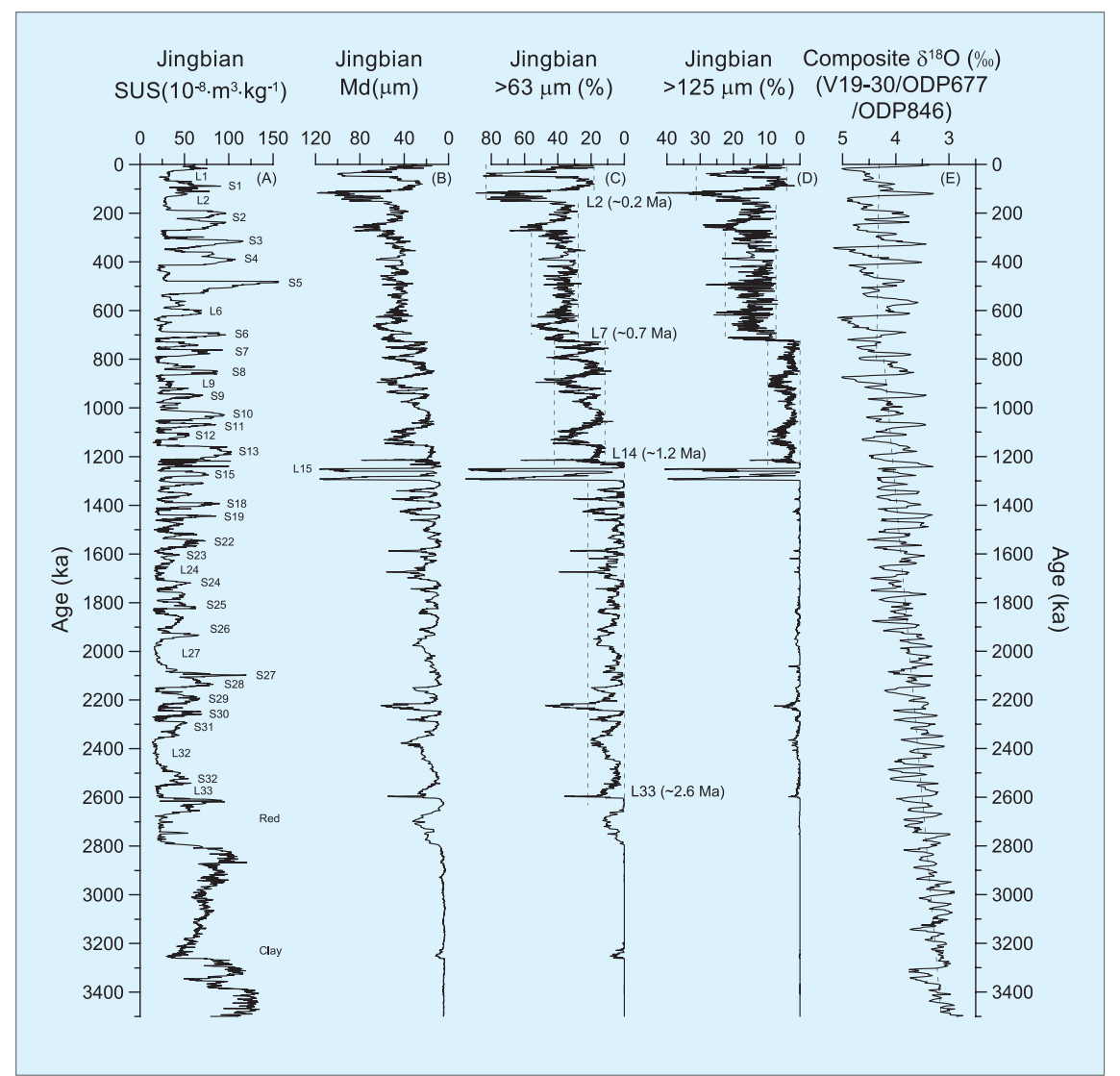

Fig. 3: Changes in magnetic susceptibility (A) and grain size data $(B, C, D)$ at Jingbian, and correlation with a stacked marine $\delta^{18} \mathrm{O}$ record (E) (Shackleton and Pisias, 1985; Shackleton et al., 1990, 1995). The timescale of the Jingbian section was developed by correlating the loess-soil units with the Chiloparts record (Ding et al., 2002). 
records (Fig. 3C and D) at Jingbian show four stepped increases in sandsized particle content. The late Pliocene red clay (below L33) contains few sand particles, indicating that the dust was transported in suspension, mainly from a remote source. From $\sim 2.6$ to $\sim 1.2 \mathrm{Ma}$, sand content in interglacial soils remains low, whereas it varies generally between $18 \%$ and $25 \%$ in glacial loess, except for the case of L15 and L16. This suggests that during glacial periods, the desert environment advanced to a location no more than $200 \mathrm{~km}$ from the present northern margin of the Loess Plateau. In the part of the section deposited between $\sim 1.2$ and $\sim 0.7 \mathrm{Ma}$, sand content increases to $\sim 12 \%$ in soils and to $\sim 43 \%$ in loess, with a substantial increase in $>125$ $\mu \mathrm{m}$ particles, implying a large-scale advance of the desert margin during both glacial and interglacial times. Throughout, material deposited in the interval $\sim 0.7-0.2 \mathrm{Ma},>63 \mu \mathrm{m}$ par- ticles range from $\sim 30 \%$ in soils and $\sim 55 \%$ in loess units, with the $>125$ $\mu \mathrm{m}$ particles exceeding $8 \%$. This suggests that the distance between the Loess Plateau and the present desert margin was less than $100 \mathrm{~km}$. During the last two glacial periods, eolian sand was directly deposited at Jingbian, indicating a further southward desert shift.

The Jingbian sand-sized particle record clearly demonstrates that, superimposed on the glacial-interglacial oscillations, the Mu Us Desert experienced significant expansion at $\sim 2.6, \sim 1.2, \sim 0.7$ and $\sim 0.2 \mathrm{Ma}$, directly implying a stepwise southward retreat of the monsoon rainfall belt, associated with a complementary reduction in summer monsoon strength, in the past $3.5 \mathrm{Ma}$. This evolutionary pattern may be causally linked to the Plio-Pleistocene increase in global ice volume, as shown in the marine oxygen isotope record (Fig. 3E).

\section{REFERENCES}

Ding Z.L., Sun, J., and Liu, T., 1999: Stepwise advance of the Mu Us desert since late Pliocene: Evidence from a red clay-loess record, Chin. Sci. Bull. 44:1211-1214

Ding Z.L., Derbyshire, E., Yang, S.L., Yu, Z.W., Xiong, S.F. and Liu, T.S., 2002: Stacked 2.6-Ma grain size record from the Chinese loess based on five sections and correlation with the deep-sea $\delta 180$ record, Paleoceanography 17, 1033, doi: 10.1029/2001PA000725.

Pye K., 1987: Aeolian Dust and Dust Deposits, Academic Press, London.

Shackleton N.J. and Pisias, N.G., 1985: Atmospheric carbon dioxide, orbital forcing, and climate, in: E.T. Sundquist, W.S. Broecker (Eds.), The Carbon Cycle and Atmospheric CO2: Natural Variations, Archean to Present, Geophysical Monograph Series 32. American Geophysical Union, Washington, DC, pp. 303-317.

Shackleton N.J., Berger, A., and Peltier, W.R., 1990: An alternative astronomical calibration of the lower Pleistocene timescale based on ODP site 677, Trans. R. Soc. Edinburgh Earth Sci. 81 251-261.

For full references please consult: www.pages-igbp.org/products/newsletters/ref2005_2.html

\title{
Human-induced Changes of Organic Carbon Storage in Soils of China
}

\author{
Zhengtang Guo ${ }^{1,2}$, Haibin Wu ${ }^{1,2}$ and Changhui Peng ${ }^{3}$ \\ ${ }^{1}$ Institute of Earth Environment, Chinese Academy of Sciences, Xi'an 710075, China; ztguo@mail.igcas.ac.cn \\ ${ }^{2}$ Institute of Geology and Geophysics, Chinese Academy of Sciences, Beijing 100029, China \\ ${ }^{3}$ Institiute of Environment Sciences, University of Quebec at Montreal, Montreal, QC H3C 3P8, Canada
}

In the last two centuries, land use has been a significant source of atmospheric $\mathrm{CO}_{2}$ through conversion of natural vegetation to farming land (Houghton, 1999; Lal, 2004). It has been estimated to be about half of the $\mathrm{CO}_{2}$ emission from the combustion of fossil fuels over the period from 1850 to 1990 (Houghton, 1999). In terrestrial ecosystems, soil organic carbon (SOC) is the largest terrestrial carbon pool. Because SOC generally has a slower turnover rate, it may be preserved for a longer time (IGBPTerrestrial Carbon Working Group, 1998). The huge carbon pool of soils and the significant changes of SOC related to land use by human activity suggest a considerable potential to enhance the rate of carbon sequestration in soils through suitable management, and thereby to decrease the atmospheric $\mathrm{CO}_{2}$ level.

A number of efforts have been carried out to determine the changes of SOC storage induced by land use at regional and global scales. However, because of the high inherent natural variability in the world's soils and variable dynamics of carbon loss under different land uses, accurate estimates of the historic loss are usually hampered by the lack of the required baseline data on soils. More exact estimates on the size of the human-induced changes of SOC storage from natural to current conditions at regional scale are very much needed, especially based on greater data density with direct field measurements. This would provide a basis for a better understanding of the future SOC sequestration from the atmosphere, as well as its role in carbon cycles.

Currently, China has 137.5 million ha of cropland (NSSO, 1998), and the long history of agricultural exploitation and the changes of land use suggest that the terrestrial ecosystem of China would have played an important role in the global carbon cycle. In this study, the spa- tial patterns of soil organic carbon density and storage under natural conditions and those under present-day conditions are investigated comparatively, based on the 34,411 soil profiles analyzed from China's second national soil survey (NSSO, 1998). Among these, 2,553 profiles were considered the most representative based on their geomorphological units, hydrothermal conditions, morphological peculiarities, physicochemical characters, and landuse conditions. According to the land-use conditions, they were then divided into two basic groups. 923 profiles are regarded in this study as natural profiles as they were not cultivated in the land-use history and the profiles had not experienced disturbance by human activity. Their current vegetation are ecologically consistent with the climatic conditions. The other 1,630 profiles were all considered cultivated profiles, including the present-day cultivated soils and those cultivated in the 